Asian-Australasian Journal of

Bioscience and Biotechnology

ISSN 2414-1283 (Print) 2414-6293 (Online)

www.ebupress.com/journal/aajbb

\title{
Article \\ Interactive effect of variety and potassium fertilizer on the yield of salt-tolerant Boro rice
}

Kawsar Hossen ${ }^{1}$, Sadia Sultana ${ }^{1}$, Md. Mahfuzar Rahman ${ }^{1}$, Ruhul Amin Rana ${ }^{1}$, Tahmina Ferdous ${ }^{2}$, Akhinur Shila ${ }^{3}$ and Rayhan Ahmed ${ }^{1 *}$

${ }^{1}$ Department of Agriculture, Noakhali Science and Technology University, Noakhali, Bangladesh

${ }^{2}$ Department of Agricultural Economics, Bangabandhu Sheikh Mujibur Rahman Agricultural University, Gazipur, Bangladesh

${ }^{3}$ Department of Agricultural Botany, Patuakhali Science and Technology University, Patuakhali, Bangladesh

*Corresponding author: Rayhan Ahmed, Department of Agriculture, Faculty of Science, Noakhali Science and Technology University, Noakhali-3814, Bangladesh. Phone: +8801717402875; E-mail: rayhan.rimon@gmail.com

Received: 24 March 2020/Accepted: 26 April 2020/ Published: 30 April 2020

\begin{abstract}
Performance of salt-tolerant Boro rice was investigated under the interaction effect of variety and different doses of potassium fertilizer, which is a part of the research for developing agriculture in coastal areas of Bangladesh. A field experiment was conducted at the research field of Agriculture department, Noakhali Science and Technology University (NSTU), Noakhali-3814. The experiment was carried out in a Randomized Complete Block Design (RCBD) with three replications where two varieties viz. BINA dhan-8, BRRI dhan-28 and three doses of potassium viz. $120 \mathrm{~kg} / \mathrm{ha}, 84 \mathrm{~kg} / \mathrm{ha}$ and $36 \mathrm{~kg} / \mathrm{ha}$ were used as treatments. Plant height $(\mathrm{cm})$, tillers/hill, grain/panicle, 1000 grain weight (g), grain yield (t/ha), straw yield (t/ha) and harvest index (\%) were compared among varieties and treatments. Results revealed that only variety and only potassium fertilizer had non-significant influence but the interaction of variety and potassium fertilizer had a significant effect on the performance of salt-tolerant Boro rice. Therefore, the present study suggests that salt-tolerant BINA dhan- 8 variety may be cultivated with $120 \mathrm{~kg}$ potassium/ha for obtaining higher yield in the southern coastal area of Bangladesh.
\end{abstract}

Keywords: Boro rice; coastal area; variety; potassium; interaction

\section{Introduction}

Agriculture is the most important sector of the Bangladeshi economy that contributes more than $15 \%$ to the national GDP (Gross Domestic Product) and provides employment opportunities for $43 \%$ of the total population. The Rice sector contributes one-half of the agricultural GDP and one-sixth of the national income in Bangladesh (BBS, 2018). Bangladesh is one of the most important rice-growing countries of the world. Bangladesh ranks fourth in terms of rice production (FAOSTAT, 2012) and third on the basis of (FAPRI, 2009) rice consumption in the world. In Bangladesh, rice is the most important leading cereal crop. Sufficient production of rice is the main way to ensure food security in Bangladesh. In fact, 'Food security' can be called as 'Rice security' in Bangladesh as in many other rice-growing countries (Brolley, 2015). Rice security is not only an economic issue but also an important factor for determining social and political strength (Nath, 2015). According to BBS, 2016 the total cultivated area of rice per year is 15.03 million hectares and total production per year about 38.34 million metric tons in Bangladesh. Besides, 79 percent of the total cropped area is also covered by rice in Bangladesh (BBS, 2015). In Bangladesh, rice can be grown in three distinct seasons: Aus, Aman and Boro. Among these, Boro rice alone provides about $56 \%$ of total food grains and also highest in productivity (3.965 metric tons per hectare) compared to Aus rice and Aman rice (BBS, 2015). With respect to 
high yield and contribution to rice production, Boro rice can be considered as one of the most important rice crops for Bangladesh (Chamely et al., 2015).

As the population of our country is increasing and cultivable land area is decreasing every year, the yield per unit area needs to be increased to meet the future food demand in the country. This could be done in many ways of which, the most effective means are the cultivation of improved varieties and proper nutrient management (Salam et al., 2011).

Variety is an important genetic factor that contributes a lot to produce a higher yield. However, the potential for increasing rice production strongly depends on the ability to integrate better crop management for the different varieties into existing cultivation systems (Mikkelsenet et al., 1995).

Potassium (K) plays an important role in the growth and development of rice (Rabbani et al., 2017). Potassium is the third major nutrient element that is absorbed by plants in a larger amount than any other nutrients. Modern high-yielding rice varieties remove a much higher amount of $\mathrm{K}$ than Phosphorus $(\mathrm{P})$ and Nitrogen $(\mathrm{N})$ (Choudhury et al., 1997; Liu et al., 2009; Sharma et al., 2013). It is also important for basic physiological functions such as the formation and translocation of the sugar, the synthesis of protein, cell division and growth (Samer et al., 1990). Considering the above facts, the present study was undertaken to observe the varietal performance of Boro rice, to evaluate the effect of rate of potassium on the yield of Boro rice and for assessing the interaction effect of variety and rate of potassium.

\section{Materials and Methods}

\subsection{Location and time}

The experiment was carried out at the research field of Agriculture department, Noakhali Science and Technology University (NSTU), Noakhali-3814 from November 2018 to May 2019. The experimental field belongs to the agro-ecological region of the Young Meghna Estuarine Floodplain (AEZ-18). The experiment field was almost level having sandy loam soil and moderately alkaline (SRDI, Noakhali), with pH value 7.5 and electrical conductivity $0.91 \mathrm{dSm}^{-1}$. The $\mathrm{pH}$ value was measured by a $\mathrm{pH}$ Meter (Hach sensION+ PH1 Basic Portable $\mathrm{pH}$ Meter) and electrical conductivity by an EC meter (sensION+ EC7). The experimental area is under the tropical climate with an average annual temperature of $25.6{ }^{\circ} \mathrm{C}$ and the average annual rainfall about 3,302 mm (Weather Station, Maizdee, Noakhali).

\subsection{Experimental treatments and design}

Two factors included in the experiment were as follows: Factor A: Variety (2); $\mathrm{V}_{1}$ - BINA dhan-8, $\mathrm{V}_{2}$ - BRRI dhan-28 and Factor B: Treatments (3); $\mathrm{T}_{1^{-}} 120 \mathrm{~kg} \mathrm{~K} / \mathrm{ha}, \mathrm{T}_{2^{-}} 84 \mathrm{~kg} \mathrm{~K} / \mathrm{ha}, \mathrm{T}_{3^{-}}-36 \mathrm{~kg} \mathrm{~K} / \mathrm{ha}$. Seeds of BINA dhan-8 were collected from Bangladesh Institute of Nuclear Agriculture (BINA), Mymensingh-2202 and BRRI dhan-28 were collected from Bangladesh Rice Research Institute (BRRI), Gazipur, Bangladesh. The experiment was laid out in a Randomized Complete Block Design (RCBD) with three replications. The size of the unit plot was 3.0 $\mathrm{m} \times 2.0 \mathrm{~m}$, having an area of $6 \mathrm{~m}^{2}$. Thus the total number of the unit plot was $18(3 \times 3 \times 2)$. A spacing of $1.0 \mathrm{~m}$ and $0.5 \mathrm{~m}$ was maintained between the replications and unit plot respectively.

\subsection{Raising of seedlings}

The collected seeds were soaked in the water for 24 hours. Then they were taken out of the water, covered with wet gunny bags and kept for sprouting. The seed started sprouting after 48 hours and almost all seeds were sprouted after 72 hours. Pre-germinated seeds of the variety BINA dhan- 8 and BRRI dhan- 28 were broadcasted uniformly in a well-prepared nursery bed on 16 December 2018.

\subsection{Land preparation and fertilization}

The land was prepared by plowing and cross-plowing by a tractor and subsequently leveled by laddering. The field was fertilized with triple superphosphate (TSP), gypsum and zinc sulfate at the rate of $120 \mathrm{~kg}, 120 \mathrm{~kg}$ and $60 \mathrm{~kg}$ per hector respectively during land preparation and urea $(220 \mathrm{~kg}$ per hector) was applied as top dressing in three equal splits at 15, 30 and 45 days after transplanting (DAT). Muriate of potash was applied as per treatment $\left(\mathrm{T}_{1^{-}}-120 \mathrm{~kg} \mathrm{~K} / \mathrm{ha}, \mathrm{T}_{2^{-}} 84 \mathrm{~kg} \mathrm{~K} / \mathrm{ha}, \mathrm{T}_{3}-36 \mathrm{~kg} \mathrm{~K} / \mathrm{ha}\right)$.

\subsection{Uprooting and transplanting of seedlings}

Seedlings were uprooted carefully from the nursery bed and were transplanted in the unit plots on 25 January 2019 maintaining the spacing of $25 \mathrm{~cm} \times 15 \mathrm{~cm}$ (row to row and plant to plant) at the rate of $1-2$ seedlings/hill. Two hand weeding was done at 20 and 35 days after transplanting (DAT). The field was irrigated from the nearest water source (pond) by irrigation devices when necessary. 


\subsection{Data collection and analysis}

Ten hills (excluding border hills) were selected randomly from each unit plot and uprooted before harvesting for recording data. Harvesting was done when $90 \%$ of the grain became golden yellow in color. The harvested crop of each unit area was separately bundled, properly tagged and then brought to the threshing floor. The harvested crop was threshed by pedal thrasher. Grains were then sun-dried at $14 \%$ moisture level and cleaned. Straws were also sun-dried properly. Data were collected on plant height $(\mathrm{cm})$, tillers/hill, grain/panicle, 1000 grain weight $(\mathrm{g})$, grain yield (t/ha), straw yield (t/ha) and harvest index $(\%)$. Plant height (selected ten plants) was measured from the ground level to the tip of the longest panicle. Tillers that had at least one leaf visible were counted. Presence of any food material in the spikelet was considered as grain and the number of grain present in each panicle was counted. One thousand clean dried seed from the seed lot of each unit area were counted separately and weight by an electrical balance. The grain and straw yield per plot was recorded and finally converted to t/ha. Harvest index is the ratio of the economic yield to the total biological yield of a crop and was calculated with the following formula.

Harvest index $(\%)=\quad($ Grain yield $\div$ Biological yield $) \times 100$

Where, Economic yield $=$ Grain yield and Biological yield $=$ Grain yield + Straw yield .

Data recorded for growth, yield and yield contributing characters were compiled and tabulated in proper form for statistical analyses. Analysis of variance was done with the help of R-Studio.

\section{Results and Discussion}

\subsection{Effect of variety on the performance of salt-tolerant Boro rice}

Variety had a non-significant effect on yield and yield contributing characters of Boro rice (Table 1).

The tallest plant height $(91.02 \mathrm{~cm})$ was obtained in BINA dhan- 8 and the smallest plant height $(87.7 \mathrm{~cm})$ was obtained from BRRI dhan-28. Sarker et al. (2013) reported shorter plant height in BRRI dhan-28 among different varieties of boro rice which is similar to our result. Some researcher (Alam et al., 2012; Shel et al., 2015; Islam et al., 2015) also reported some results which are more or less similar to our result.

BRRI dhan-28 (15.71) produced more tiller/hill than BINA dhan-8 (13.99) and the result is consistent with some other researcher (Tyeb et al., 2013; Sarker et al., 2013; Islam et al., 2015)

BRRI dhan-28 (117.33) had less grain/panicle compare to BINA dhan-8 (121.47). Tyeb et al., (2013) conducted an experiment with four varieties of rice and reported that variety BRRI dhan-52 produced more number of grains/panicle than other varieties.

Weight of thousand grain was more or less similar between BINA dhan-8 (23.63) and BRRI dhan-28 (23.16). Islam et al. (2015) found the higher 1000-grain weight (25.49 g) in BR-11 and the lower one (21.33 g) in BRRI dhan-49 which indicates less variation between two varieties.

Less difference also found for grain yield (t/ha.) between BINA dhan-8 (6.76) and BRRI dhan-28 (6.45). Sultana et al. (2012) carried out an experiment with three rice varieties viz. BR-11, BRRI Dhan-51 and BRRI dhan-52 and found that BRRI dhan-51 produced highest harvest yield compared to the other two varieties. In our experiment, BINA dhan-8 gave the highest grain yield (t/ha.) compared to BRRI dhan-28.

The highest straw yield (t/ha.) was found in BINA dhan-8 (5.51) in comparison with BRRI dhan-28 (4.84). Rajaul (2005) observed the highest straw yield (5.54 t/ha) in BRRI dhan-29 and lowest (5.43 t/ha) in BRRI dhan-28 that supports our result.

BRRI dhan-28 (56.56) showed the highest harvest index (\%) than BINA dhan-8 (54.93). Arshad (2009) conducted an experiment with three rice varieties viz. BINA dhan-4, BRRI dhan-40, and BRRI dhan-41 and reported that the highest harvest index (41.9\%) was obtained by BRRI dhan-40 and the lowest one (40.08\%) was obtained from BRRI dhan-41.

\subsection{Effect of potassium fertilizer on the performance of salt-tolerant Boro rice}

Different doses of potassium fertilizer had a non-significant effect on yield and yield contributing characters of Boro rice (Table 2).

Here, more or less same plant height $(\mathrm{cm})$ was obtained from $\mathrm{T}_{1}(90.93)$ and $\mathrm{T}_{2}(90.35)$ but $\mathrm{T}_{3}$ showed the lowest plant height (73.04). Balliu and Ibro (2002) stated no evidence of any significant difference in plant height due to the different amounts of potassium supply.

The highest number of tiller/hill was observed from $T_{1}$ (16.5) and lowest in $T_{2}$ (14.17). $T_{2}$ and $T_{3}$ showed statistically more or less similar result. Qiangsheng et al. (2004) observed that the number of effective tillers/hill increased with increasing $\mathrm{K}$ rates which is consistent with our result. 
The number of grains per panicle increased with the increase of potassium fertilizer. The highest number of grains/panicle found from $\mathrm{T}_{1}$ (125.67) and lowest from $\mathrm{T}_{3}$ (110.92). Talukder et al. (1992) found that application up to $60 \mathrm{~kg} \mathrm{~K}_{2} \mathrm{O} /$ ha mainly increased the filled grains/panicle.

Potassium fertilizer showed little/no effect on the thousand-grain weight (g). A more or less statistically similar result $\left(23.42,23.0\right.$, and 23.77) was found for $\mathrm{T}_{1}, \mathrm{~T}_{2}$, and $\mathrm{T}_{3}$ respectively. Choudhury et al. (1993) stated that the application of $\mathrm{K}$ favorably influenced yield components.

A slightly increasing trend was found for grain yield ( $t / h a)$ and straw yield ( $t / h a)$ with the increase of potassium fertilizer doses. For both grain and straw yield, the highest value found in $T_{1}$ and lowest from $T_{3}$. According to BRRI (1990), the application of only $30 \mathrm{~kg} \mathrm{~K} / \mathrm{ha}$ increased the grain yield slightly over control at most of the locations. The yield of grain and straw also increased due to the application of $150 \mathrm{~kg} \mathrm{~K}_{2} \mathrm{O} / \mathrm{ha}$ (Choudhury et al., 1993).

Potassium fertilizer had little effect on harvest index $(\%)$ and the highest value was found in $\mathrm{T}_{2}(56.61)$ and lowest in $\mathrm{T}_{3}$ (45.39). Amanullah et al. (2015) recorded the highest harvest index (39.2\%) for the plots treated with the highest $\mathrm{K}$ level (90 kg ha-1). Potassium application improved the crop harvest index and grain quality parameters of boldness, protein, and oil contents (Umar et al., 1999).

\subsection{Effect of interaction between variety and potassium fertilizer on the performance of salt-tolerant Boro rice}

The interaction of variety and potassium fertilizer exhibited significant influence on yield and yield contributing characters of salt-tolerant Boro rice except for number of tillers/plant and number of grains/plant (Table 3).

Plant height $(\mathrm{cm})$ varied significantly with the interaction of variety and potassium fertilizer. The highest plant height $\left(101.63 \mathrm{~cm}\right.$ ) was found in the treatment combination of $\mathrm{V}_{1} \mathrm{~T}_{2}$ (BINA dhan-8 and $84 \mathrm{~kg} \mathrm{~K} / \mathrm{ha}$ ) and the lowest plant height $(82.37 \mathrm{~cm})$ was observed in $\mathrm{V}_{2} \mathrm{~T}_{3}$ (BRRI dhan-28 and $36 \mathrm{~kg} \mathrm{~K} / \mathrm{ha}$ ).

Interaction between variety and fertilizer doses of potassium had a non-significant effect on number of tillers/plant and number of grains/panicle. The highest number of tiller/hill (14.13) was found in the treatment combination $\mathrm{V}_{1} \mathrm{~T}_{1}$ (BINA dhan-8 and $120 \mathrm{~kg} \mathrm{~K} / \mathrm{ha}$ ) and lowest number of tiller/hill (10.67) was observed in $\mathrm{V}_{2} \mathrm{~T}_{2}$ (BRRI dhan-28 and $84 \mathrm{~kg} \mathrm{~K} / \mathrm{ha}$ ). On the other hand, maximum grain/panicle (136.23) was identified in the treatment combination of $\mathrm{V}_{1} \mathrm{~T}_{3}$ (BINA dhan-8 and $36 \mathrm{~kg} \mathrm{~K} / \mathrm{ha}$ ) and minimum grain/panicle (106.53) was found in $\mathrm{V}_{2} \mathrm{~T}_{1}$ (BRRI dhan-28 and $120 \mathrm{~kg} \mathrm{~K} / \mathrm{ha}$ ).

1000 grain weight $(\mathrm{g})$ was influenced significantly by the interaction effect of variety and potassium fertilizer. The maximum weight of 1000 grain $\left(39.17 \mathrm{~g}\right.$ ) was found in the treatment combination $\mathrm{V}_{2} \mathrm{~T}_{3}$ (BRRI dhan-28 and $36 \mathrm{~kg} \mathrm{~K} / \mathrm{ha})$. On the other hand, minimum weight of 1000 grain $(21.67 \mathrm{~g})$ was observed in $\mathrm{V}_{1} \mathrm{~T}_{2}$ (BINA dhan-8 and $84 \mathrm{~kg} \mathrm{~K} / \mathrm{ha}$ ).

Interaction of variety and potassium fertilizer significantly influenced grain yield and straw yield. The highest grain yield ( $8.43 \mathrm{t} / \mathrm{ha}$ ) was found in the treatment combination of $\mathrm{V}_{1} \mathrm{~T}_{1}$ (BINA dhan-8 and $120 \mathrm{~kg} \mathrm{~K} / \mathrm{ha}$ ) and lowest grain yield $\left(5.03 \mathrm{t} / \mathrm{ha}\right.$ ) was observed in $\mathrm{V}_{2} \mathrm{~T}_{3}$ (BRRI dhan-28 and $36 \mathrm{~kg} \mathrm{~K} / \mathrm{ha}$ ). Similarly, the highest straw yield (8.90 t/ha) was found in the treatment combination of $\mathrm{V}_{1} \mathrm{~T}_{1}$ (BINA dhan-8 and $120 \mathrm{~kg} \mathrm{~K} / \mathrm{ha}$ ). On the other hand, lowest straw yield (5.93 t/ha) was observed in $\mathrm{V}_{2} \mathrm{~T}_{1}$ (BRRI dhan-8 and $120 \mathrm{~kg} \mathrm{~K} / \mathrm{ha}$ ).

Harvest index $(\%)$ also affected significantly by the interaction effect of variety and potassium fertilizer. The highest harvest index $\left(52.14 \%\right.$ ) was found in the treatment combination of $\mathrm{V}_{2} \mathrm{~T}_{1}$ (BRRI dhan-28 and $120 \mathrm{~kg}$ $\mathrm{K} / \mathrm{ha}$ ). On the other hand, lowest harvest index (42.52\%) was observed in $\mathrm{V}_{2} \mathrm{~T}_{3}$ (BRRI dhan-28 and $36 \mathrm{~kg}$ $\mathrm{K} / \mathrm{ha}$ ).

Table 1. Effect of variety on the performance of salt-tolerant Boro rice.

\begin{tabular}{|l|l|l|l|l|l|l|l|}
\hline Variety & $\begin{array}{l}\text { Plant } \\
\text { height } \\
(\mathbf{c m})\end{array}$ & $\begin{array}{l}\text { Tiller/ } \\
\text { hill }\end{array}$ & $\begin{array}{l}\text { Grain/ } \\
\text { panicle }\end{array}$ & $\begin{array}{l}\text { 1000 grain } \\
\text { weight }(\mathbf{g})\end{array}$ & $\begin{array}{l}\text { Grain } \\
\text { yield } \\
\text { (t/ha) }\end{array}$ & $\begin{array}{l}\text { Straw } \\
\text { yield } \\
\text { (t/ha) }\end{array}$ & $\begin{array}{l}\text { Harvest } \\
\text { index }(\%)\end{array}$ \\
\hline BINA dhan-8 & 91.02 & 13.99 & 121.47 & 23.63 & 6.76 & 5.51 & 54.93 \\
\hline BRRI dhan-28 & 87.7 & 15.71 & 117.33 & 23.16 & 6.45 & 4.84 & 56.56 \\
\hline Mean & 89.36 & 14.85 & 119.4 & 23.4 & 6.6 & 5.18 & 55.75 \\
\hline std & 2.35 & 1.22 & 2.93 & 0.33 & 0.22 & 0.47 & 1.15 \\
\hline Cv (\%) & 2.63 & 8.22 & 2.45 & 1.41 & 3.33 & 9.07 & 2.06 \\
\hline $\begin{array}{l}\text { Level of } \\
\text { significance }\end{array}$ & NS & NS & NS & NS & NS & NS & NS \\
\hline
\end{tabular}


Table 2. Effect of different doses of potassium fertilizer on the performance of salt-tolerant Boro rice.

\begin{tabular}{|l|l|l|l|l|l|l|l|}
\hline Treatment & $\begin{array}{l}\text { Plant } \\
\text { height } \\
(\mathbf{c m})\end{array}$ & $\begin{array}{l}\text { Tiller/ } \\
\text { hill }\end{array}$ & $\begin{array}{l}\text { Grain/ } \\
\text { panicle }\end{array}$ & $\begin{array}{l}\mathbf{1 0 0 0} \text { grain } \\
\text { weight }(\mathbf{g})\end{array}$ & $\begin{array}{l}\text { Grain } \\
\text { yield (t/h) }\end{array}$ & $\begin{array}{l}\text { Straw } \\
\text { yield (t/h) }\end{array}$ & $\begin{array}{l}\text { Harvest } \\
\text { index } \\
(\mathbf{\%})\end{array}$ \\
\hline $\mathrm{T}_{1}(120 \mathrm{~kg} \mathrm{~K} / \mathrm{ha})$ & 90.93 & 16.5 & 125.67 & 23.42 & 6.91 & 5.22 & 54.39 \\
\hline $\mathrm{T}_{2}(84 \mathrm{~kg} \mathrm{~K} / \mathrm{ha})$ & 90.35 & 14.17 & 121.62 & 23.0 & 6.72 & 5.16 & 56.61 \\
\hline $\mathrm{T}_{3}(36 \mathrm{~kg} \mathrm{~K} / \mathrm{ha})$ & 73.04 & 14.23 & 110.92 & 23.77 & 6.2 & 5.14 & 45.39 \\
\hline Mean & 84.77 & 14.97 & 119.40 & 23.39 & 6.61 & 5.17 & 52.13 \\
\hline std & 10.17 & 1.33 & 7.62 & 0.39 & 0.37 & 0.04 & 5.94 \\
\hline $\mathrm{cv}$ & 11.99 & 8.88 & 6.38 & 1.65 & 5.56 & 0.82 & 168.71 \\
\hline $\begin{array}{l}\text { Level of } \\
\text { significance }\end{array}$ & $\mathrm{NS}$ & $\mathrm{NS}$ & $\mathrm{NS}$ & $\mathrm{NS}$ & $\mathrm{NS}$ & $\mathrm{NS}$ & $\mathrm{NS}$ \\
\hline
\end{tabular}

Table 3. Effect of interaction between variety and fertilizer doses of potassium on the performance of salttolerant Boro rice.

\begin{tabular}{|l|l|l|l|l|l|l|l|}
\hline Treatment & $\begin{array}{l}\text { Plant } \\
\text { height }(\mathbf{c m})\end{array}$ & $\begin{array}{l}\text { Tiller/ } \\
\text { hill }\end{array}$ & $\begin{array}{l}\text { Grain/ } \\
\text { panicle }\end{array}$ & $\begin{array}{l}\text { 1000 grain } \\
\text { weight }(\mathbf{g})\end{array}$ & $\begin{array}{l}\text { Grain yield } \\
\text { (t/ha) }\end{array}$ & $\begin{array}{l}\text { Straw } \\
\text { Yield (t/ha) }\end{array}$ & $\begin{array}{l}\text { Harvest } \\
\text { index }(\%)\end{array}$ \\
\hline $\mathrm{V}_{1} \mathrm{~T}_{1}$ & 95.23 & 14.13 & 126.77 & 23.77 & 8.43 & 8.90 & 48.65 \\
\hline $\mathrm{V}_{1} \mathrm{~T}_{2}$ & 101.63 & 13.40 & 130.30 & 21.67 & 7.30 & 7.73 & 48.52 \\
\hline $\mathrm{V}_{1} \mathrm{~T}_{3}$ & 89.23 & 12.03 & 136.23 & 22.83 & 6.0 & 6.17 & 49.31 \\
\hline $\mathrm{V}_{2} \mathrm{~T}_{1}$ & 90.77 & 11.10 & 106.53 & 26.17 & 6.47 & 5.93 & 52.14 \\
\hline $\mathrm{V}_{2} \mathrm{~T}_{2}$ & 83.57 & 10.67 & 106.70 & 28.93 & 6.67 & 6.30 & 51.40 \\
\hline $\mathrm{V}_{2} \mathrm{~T}_{3}$ & 82.37 & 10.40 & 110.47 & 39.17 & 5.03 & 6.80 & 42.52 \\
\hline Mean & 90.47 & 11.96 & 119.50 & 27.09 & 6.65 & 6.97 & 48.76 \\
\hline std & 7.24 & 1.52 & 13.14 & 6.46 & 1.16 & 1.14 & 3.40 \\
\hline $\mathrm{CV}(\%)$ & 8.00 & 12.75 & 10.99 & 23.85 & 17.37 & 16.36 & 6.97 \\
\hline $\begin{array}{l}\text { Level of } \\
\text { significance }\end{array}$ & $* *$ & $\mathrm{NS}$ & $\mathrm{NS}$ & $* * *$ & $* * *$ & $* * *$ & $* * *$ \\
\hline
\end{tabular}

NS = Non Significant

$* * *=$ Significant at $0.1 \%$ level of probability

${ }^{* *}=$ Significant at $1 \%$ level of probability

$*$ = Significant at $5 \%$ level of probability

\section{Conclusions}

The only variety and potassium fertilizer doses had a non-significant effect but the interaction of variety and potassium fertilizer doses had a significant influence on yield and yield contributing characters of Boro rice. After considering all results as references, we can conclude that the highest yield obtained from the combination of BINA dhan-8 variety and treatment $120 \mathrm{~kg}$ potassium $/ \mathrm{ha}\left(\mathrm{V}_{1} \mathrm{~T}_{1}\right)$. However, to attain a final decision more research work on Boro rice with the same treatment should be done in different Agro-ecological Zones (AEZs) of Bangladesh.

\section{Conflict of interest}

None to declare.

\section{References}

Alam MS, MA Baki, MS Sultana, KJ Ali and MS Islam, 2012. Effect of variety, spacing and number of seedlings per hill on the yield potentials of transplant aman rice. Int. J. Agr. \& Agri., 2: 10-15.

Amanullah A, A Iqbal and M Iqbal, 2015. Impact of potassium rates and their application time on dry matter partitioning, biomass and harvest index of maize (Zea mays) with and without cattle dung application. Emir. J. Food Agr., 27: 447.

Arshad HM, 2009. Effect of cultivar and planting method on the performance of transplant aman rice. MS thesis, Department of Agronomy, Bangladesh Agricultural University, Mymensingh. pp. 39.

Balliu A and V Ibro, 2002. Influence of different levels of potassium fertilizers on growth, yield and ascorbic acid content of tomato fruit grown in non-heated greenhouse. Acta Hortic., 579: 385-388. 
BBS, 2015. Statistical Year Book of Bangladesh. Bangladesh Bur. Stat., Stat. Div., Min. Plan., Govt. People's Repub. Bangladesh, Dhaka.

BBS, 2016. Statistical Year Book of Bangladesh. Bangladesh Bur. Stat., Stat. Div., Min. Plan., Govt. People's Repub. Bangladesh, Dhaka.

BBS, 2018. Statistical Year Book of Bangladesh. Bangladesh Bur. Stat., Stat. Div., Min. Plan., Govt. People's Repub. Bangladesh, Dhaka.

Brolley M, 2015. Rice security is food security for much of the world. Rice Today. International Rice Research Institute (IRRI), DAPO Box 7777, Metro Manila, Philippines. pp. 30-32.

BRRI, 1990. Annual report for 1984 Bangladesh Rice Res. Inst., Joydevpur, Gazipur. Bangladesh Rice Research Institute.

Chamely SG, N Islam, S Hoshain, MG Rabbani, MA Kader and MA Salam, 2015. Effect of variety and nitrogen rate on the yield performance of boro rice. Progressive Agriculture, 26: 6-14.

Choudhury ATMA, SK Zaman and NI Bhuiyan, 1997. Prospect of mixed fertilizer application in wetland rice culture. Thai J. Agril. Sci., 30: 477-482.

Choudhury MS, 1993. Effect of variety and number of seedlings/hill on the yield and its components on late transplant aman rice. Bangladesh J. Agri. Sci., 20: 311-316.

FAOSTAT, 2012. Food and Agricultural Commodities Production 2010. Food and Agriculture Organization of the United Nations. Available at http://faostat. fao.org/site/339/default.aspx.

FAPRI, 2009. The Agricultural Outlook 2009. World Rice. Food and Agricultural Policy Research Institute. Available at http://www.fapri. iastate. edu/outlook/2009/.

Islam A, J Chandrabiswas, AJMS Karim, M Salmapervin and MA Saleque, 2015. Effects of Potassium Fertilization on Growth and Yield of Wetland Rice in Grey Terrace Soils of Bangladesh. Research on Crop Ecophysiology J., 10: 64-82.

Liu G, Y Li and DM Porterfield, 2009. Genotypic differences in potassium nutrition in lowland rice hybrids. Commun. Soil Sci. Plant Anal., 40: 1803-1821.

Mikkelsen D, GR Jayaweera and DE Rolston, 1995. Nitrogen fertilization practices of lowland rice culture. Nitrogen fertilization in the environment, 171.

Nath NC, 2015. Food security in Bangladesh: Status, challenges and strategic policy options. 19th Biennial Conference of the Bangladesh Economic Association (BAE), 8-10 January 2015, Dhaka, Bangladesh.

Qiangsheng W, Z Ruohong, D Yanfeng, C Weixin and H Pisheng, 2004. Effects of potassium fertilizer application rates on plant potassium accumulation and grain quality of japonica rice. Sci. Agric. Sinica., 37: 1444-1450.

Rabbani MG, MA Kashem, MA Aziz and MS Hossain, 2017. Effect of potassium fertilizer on the growth of boro rice varieties in haor areas. J. Sylhet Agril. Univ., 4: 261-266.

Rajaul KM, 2005. Effect of weeding regime and variety on the yield components of boro rice. MS thesis, Department of Agronomy, Bangladesh Agricultural University, Mymensingh. pp. 43.

Salam MA, F Lucy, MH Kabir and AR Khan, 2011. Effect of different doses of fertilizers on yield and yield components of two varieties of boro rice. J. Agrofor. Environ., 5: 53-56.

Samer M, SM Mehdi, M Sadiq and G Hassan, 1990. Effect of Sulpur on yield and chemical composition of rice. Sarhad J. Argil., 18: 411- 414.

Sarker BC, M Zahan, UK Majumder, MA Islam and B Roy, 2013. Growth and yield potential of some local and high yielding boro rice varieties. J. Agrofor. Environ., 7: 107-110.

Sharma S, G Chander, TS Verma and S Verma, 2013. Soil potassium fractions in rice-wheat cropping system after twelve years of Lantana residue incorporation in a Northwest Himalayan acid alfisol. J. Plant Nutr., 36: $1809-1820$.

Shel SK, 2015. Effect of row spacing on growth and yield of short duration transplant aman rice varieties. MS thesis, Department of Agronomy, Bangladesh Agricultural University, Mymensingh. pp. 22-28.

Sultana M, MA Kader, MS Islam and F Zaman, 2012. Performance of transplanted aman rice under various levels and sources of nitrogen application. Bangladesh J. Environ. Sci., 23: 202-206.

Talukder R, 1992. Potassium fertilization in transplanted rice. J. potassium, 20, 158- 161.

Tyeb A, SK Paul and MA Samad, 2013. Performance of variety and spacing on the yield and yield contributing characters of transplanted aman rice. J. Agrofor. Environ. 7: 57-60.

Umar S, SK Bansal, P Imas and H Magen, 1999. Effect of foliar fertilization of potassium on yield, quality, and nutrient uptake of groundnut. J. Plant Nutr., 22: 1785-1795. 